\title{
Halomonas jincaotanensis sp. nov., a 1- naphthylamine degrading bacterium isolated from Pamir Plateau
}

\section{Xuying Bu}

College of Life Science, Tarim University

\section{Zhanfneg Xia}

College of Life Science, Tarim University

Zhanwen Liu

College of Life Science, Tarim University

Min Ren ( $\square$ renminlure@163.com )

Tarim University https://orcid.org/0000-0003-1480-9962

\section{Chuanxing Wan}

College of Life Science, Tarim University

\section{Lili Zhang}

College of Life Science, Tarim University

\section{Research Article}

Keywords: Halomonas, Jincaotan, Polyphasic taxonomy, 1-Naphthylamine, Degradation

Posted Date: November 15th, 2021

DOI: https://doi.org/10.21203/rs.3.rs-1049474/v1

License: (1) This work is licensed under a Creative Commons Attribution 4.0 International License. Read Full License 


\section{Halomonas jincaotanensis sp. nov., a 1-naphthylamine degrading bacterium isolated from Pamir Plateau}

Xuying Bu, Zhanfeng Xia, Zhanwen Liu, Min Ren*, Chuanxing Wan and Lili Zhang

State Key Laboratory Breeding Base for The Protection and Utilization of Biological Resources in Tarim Basin Co-funded by Xinjiang Corps and The Ministry of Science and Technology, College of Life Science, Tarim University, Alar, 843300, Xinjiang, PR China

\section{Author for Correspondence:Min Ren}

$$
\begin{aligned}
& \text { Tel/Fax: +869974681612 } \\
& \text { E-mail: renminlure@163.com }
\end{aligned}
$$

Running title: Halomonas jincaotanensis sp. nov.

Category: New Tax-Proteobacteria

The GenBank accession number for the genome and 16S rRNA gene sequence of strain TRM $85114^{\mathrm{T}}$ are JAHCLU000000000 and MW584241, respectively. 
2 A Gram-staining-negative, aerobic, rod-shaped bacterium, designated strain TRM

$385114^{\mathrm{T}}$, was isolated from Jincaotan wetland in Pamir Plateau, PR China.

4 According to the study, we found it have an ability to degrade 1-naphthylamine.

5 Strain TRM $85114^{\mathrm{T}}$ grow at $4-35{ }^{\circ} \mathrm{C}$ (optimum, $30^{\circ} \mathrm{C}$ ), $\mathrm{pH}$ of $6.0-9.0$ (optimum,

$6 \mathrm{pH}$ 6.0) and can tolerate 1\%-10\% (w/v) $\mathrm{NaCl}$ (optimum, 3\%). Phylogenetic

7 analysis of $16 \mathrm{~S}$ rRNA gene sequences revealed that strain TRM $85114^{\mathrm{T}}$ was

8 affiliated of the genus Halomonas, sharing high sequence similarity (97.3\%) with

9 the type strain of Halomonas korlensis $\mathrm{XK} 1^{\mathrm{T}}$. The primary cellular fatty acids of

10 strain TRM $85114^{\mathrm{T}}$ were $\mathrm{C}_{16: 0}$ and $\mathrm{C}_{19: 0}$ cyclo $\omega 8 c$. The predominate respiratory

11 quinone was Q-9. The polar lipids were diphosphatidylglycerol,

12 phosphatidylglycerol, phosphatidylethanolamine, lyso-phospatidylglycerol,

13 phospholipids of unknown structure containing glucosarmine, and five

14 unidentified lipids. The genomic DNA G+C content of strain TRM $85114^{\mathrm{T}}$ was

$1561.6 \mathrm{~mol} \%$. Calculated the average nucleotide identities and the digital

16 DNA-DNA hybridization values between strain TRM $85114^{\mathrm{T}}$ and the related type

17 Halomonas strains further revealed that TRM $85114^{\mathrm{T}}$ represented a novel species

18 of the genus Halomonas, for which the name Halomonas jincaotanensis sp. nov.

19 is proposed. The type strain is TRM $85114^{\mathrm{T}}\left(\mathrm{CCTCC}\right.$ AB $2021006^{\mathrm{T}}=\mathrm{LMG}$

$\left.20 \quad 32311^{\mathrm{T}}\right)$.

21 Keywords Halomonas; Jincaotan; Polyphasic taxonomy; 1-Naphthylamine;

22 Degradation 


\section{Introduction}

Halophilic microorganisms, especially Halomonas spp., usually have ability to accumulate polyphosphate (Nguyen et al. 2012), produce biodegradable polyhydroxyalkanoates (Tuma et al. 2020; Jiang et al. 2018) and various metabolic chemicals (Du et al. 2020; Jiang et al. 2021), for which have been the platform strain for producing multiple products in various industrial fields. Vreeland et al. (1980) initially proposed Halomonas, belongs to the family Halomonadaceae of the phylum Proteobacteria. At present, the genus contains more than 150 validly named species. Members of the genus Halomonas have been isolated from diverse terrestrial and aquatic habitats, such as lake water (Kazemi et al. 2020), saline-alkali land (Dou et al. 2015), tidal flat (Koh et al. 2017), Arctic tundra soil (Zhou et al. 2019), deep-sea sediment (Xu. et al. 2013) and hypersaline wetland (Ramezani et al. 2020). This study obtained a Halomonas-like strain isolated from Pamir Plateau, designated TRM $85114^{\mathrm{T}}$. We explored the taxonomic characterization and the ability to degrade 1-naphthylamine by strain TRM $85114^{\mathrm{T}}$.

1-Naphthylamine, as one of the top priority contaminants and carcinogens $(\mathrm{Hu}$ et al. 2011), is a derivative of polycyclic aromatic hydrocarbon, have been used as an intermediate for synthesis industries (Yang et al. 2020). The degree of human activity in industrial applications determined the concentration and transport of these ubiquitous compounds. The genus of Halomonas has shown the degradation 
ability of polycyclic aromatic hydrocarbon (Govarthanan et al. 2020; Farraj et al. 2020), which is a tremendous potential capability in environmental remediation.

\section{Materials and methods}

\section{Sample collection, isolation and preservation}

Soil sample was collected from a wetland named Jincaotan $\left(37^{\circ} 47^{\prime} \mathrm{N}, 75^{\circ} 16^{\prime} \mathrm{E}\right)$ in Pamir Plateau, at $3100 \mathrm{~m}$. Strain TRM $85114^{\mathrm{T}}$ was isolated from the sample by using general dilution-plating method. During the isolation process, $100 \mu \mathrm{L}$ of mixed water and soil sample was spread onto the $12 \%$ Modified Growth Medium (MGM) agar plate (Smith, 2009), which contained: $5 \mathrm{~g} / \mathrm{L}$ peptone (Oxoid), $1 \mathrm{~g} / \mathrm{L}$ yeast extract (Oxoid) and $400 \mathrm{~mL} / \mathrm{L}$ salt water (30\% stock) with an adjusted $\mathrm{pH}$ of 7.0, incubated for 2 weeks at $15{ }^{\circ} \mathrm{C}$. Colonies on the plates showing different morphological were picked and purified, among which strain TRM $85114^{\mathrm{T}}$ was routinely grown in $12 \% \mathrm{MGM}$ agar at $15{ }^{\circ} \mathrm{C}$. Colonies were preserved in $12 \%$ MGM containing $50 \%(\mathrm{v} / \mathrm{v})$ glycerol at $-80^{\circ} \mathrm{C}$.

The reference strain H. korlensis CGMCC $1.6981^{\mathrm{T}}$, Halomonas urumqiensis CGMCC $1.12917^{\mathrm{T}}$ and Halomonas daqiaonensis CGMCC $1.9150^{\mathrm{T}}$ were obtained from China General Microbiological Culture Collection Center (CGMCC), Halomonas tibetensis KCTC $52660^{\mathrm{T}}$ was obtained from Korean Collection for Type Cultures (KCTC), all of them cultured under the same conditions, as specified, for comparative purposes.

\section{Phenotypic and physiological identification}


Procedures for phenotypic characterization followed Mata et al. (2002) and Arahal et al. (2007). Cellular morphology was examined by light microscopy (Leica DM1000) and scanning electron microscope (SEM) (Quanta; FEI) when cells were growing on $12 \%$ MGM agar for 4 days at $30^{\circ} \mathrm{C}$. Anaerobic growth was tested on solid 12\% MGM medium by using an MGC AnaeroPack Series (MGC). Motility was observed by using 12\% MGM medium with $5 \mathrm{~g} / \mathrm{L}$ agar. Growth was tested at different temperatures $\left(4,8,16,24,28,30,32,35,37,40\right.$ and $\left.45^{\circ} \mathrm{C}\right)$ by using 12\% MGM liquid medium. Different $\mathrm{NaCl}$ concentrations $(0,1,2,3,4,5,6$, $7,8,9,10,15,20,25$ and $30 \mathrm{w} / \mathrm{v} \%$ ) tolerance were tested in basic $12 \% \mathrm{MGM}$ liquid medium without $\mathrm{NaCl}$ at $30^{\circ} \mathrm{C}$. The $\mathrm{pH}$ tolerance of strains was also tested at $30{ }^{\circ} \mathrm{C}$ by using buffered 12\% MGM liquid medium (50 mM MES (pH 5;6), HEPES (pH 7), TAPS (pH 8), CAPSO (pH 9; 10)and CAPS (pH 11)) over different $\mathrm{pH}$ range (5-11 at $1.0 \mathrm{pH}$ unit intervals). The incubation times for temperature, $\mathrm{NaCl}$, and $\mathrm{pH}$ ranges tests were 3 days. The tests for requirement of $\mathrm{Mg}^{2+}, \mathrm{SO}^{2-}$ and $\mathrm{K}^{+}$to growth, exopolysaccharide and Polyhydroxyalkanoate (PHA) production were following the method described by Poli et al. (2013). Oxidation/fermentation of D-glucose, respiration on nitrate and nitrite, $\mathrm{H}_{2} \mathrm{~S}$ production from L-cysteine, reduction of nitrate to nitrite, hydrolysis of gelatin, casein, starch, Tween $(20,40,60$, and 80$)$, aesculin and DNA, indole production, methyl red and Voges-Proskauer test, catalase, oxidase, urease, phenylalanine deaminase, lysine and ornithine decarboxylases, and $o$-Nitrophenyl- $\beta$-Dgalactopyranosidase activity, were tested according to the methods described by 
Dong et al. (2001). Rapid identification systems, including API 20E, API 20NE, and API 50CH (bioMérieux), were used to detect acid production and substrate utilization in three replicates at $30{ }^{\circ} \mathrm{C}$ for $72 \mathrm{~h}$ in accordance with the manufacturer's instructions. Antibiotic susceptibility were tested on $12 \%$ MGM agar plates inoculated with strains by using filter paper discs containing the following compounds (content per disc): ampicillin $(10 \mu \mathrm{g})$, vancomycin $(30 \mu \mathrm{g})$, carbenicillin $(100 \mu \mathrm{g})$, penicillin $(1 \mu \mathrm{g})$, oxacillin $(1 \mu \mathrm{g})$, piperacillin $(100 \mu \mathrm{g})$, cefalexin $(30 \mu \mathrm{g})$, cefradine $(30 \mu \mathrm{g})$, ceftriaxone $(30 \mu \mathrm{g})$, cefoperazone $(75 \mu \mathrm{g})$, gentamicin $(10 \mu \mathrm{g})$, kanamycin $(30 \mu \mathrm{g})$, neomycin $(30 \mu \mathrm{g})$, tetracycline $(30 \mu \mathrm{g})$, deoxytetracycline $(30 \mu \mathrm{g})$, minocycline $(30 \mu \mathrm{g})$, erythromycin $(15 \mu \mathrm{g})$, norfloxacin $(10 \mu \mathrm{g})$, ofloxacin $(5 \mu \mathrm{g})$, ciprofloxacin $(5 \mu \mathrm{g})$, polymyxin B $(300 \mu \mathrm{g})$, bactrim $(25 \mu \mathrm{g})$, clindamycin $(2 \mu \mathrm{g})$. After incubated at $30{ }^{\circ} \mathrm{C}$ for 2 days, inhibition zones were measured according to the method described by Zhong et al. (2016).

\section{Chemotaxonomic characterization}

Biomass used for studies was obtained by culturing in liquid 12\% MGM medium for 4 days in shake flasks at $30^{\circ} \mathrm{C}$. The cells were collected by centrifugation and washed with distilled water and then freeze-dried. Ubiquinone were extracted from freeze-dried biomass according to the method proposed by Collins et al. (1977), analyzed by high-performance liquid chromatography (HPLC) followed the method by Collins (1985). Cellular fatty acids were extracted from the fresh cells according to the method proposed by Sasser (1990), and analyzed by gas 
chromatography using the Microbial Identification System (Sherlock version 6.1; MIDI database: RTSBA6). TRM $85114^{\mathrm{T}}$ and four reference strains were cultivated on $12 \%$ MGM plates and harvested at the same time to detect the composition of cellular fatty acids. Polar lipids were detected by two-dimensional thin-layer chromatography and identified by the method proposed by Minnikin et al. (1984).

\section{Sequence similarity and phylogenetic analysis}

Genomic DNA of strain TRM $85114^{\mathrm{T}}$ was extracted by using a TIANGEN (Beijing, China) bacterial DNA extraction kit. The 16S rRNA gene of strain TRM $85114^{\mathrm{T}}$ was amplified and sequenced with primers 27F (5'-AGAGTTTGATCCTGGCTCAG-3') and 1492R (5'-TACCTTGTTACGACTT-3'). Housekeeping genes gyrB and $r p o D$ were amplified by using primers gyrB216F (5'-GARGTBATCATGACSGTGCT-3') and $g y r B 1419 \mathrm{R}$ (5'-GCRTCSGTCATGATGATSAY-3'), rpoD88F (5'-ATGATYAACGACATGGGYAT-3') and rpoD1321R (5'-TTSAKCTTRTTGATGGTCTC-3'), respectively. For determination of the almost full-length of 16S rRNA gene sequence, the PCR amplicons were ligated into the pMD18-T vector using a pMD18-T cloning kit (TaKaRa) according to the manufacturer's instructions. The plasmid DNA was sequenced by using primers M13F (5'-TGTAAAACGACGGCCAGT-3') and M13R (5'-CAGGAAACAGCTATGACC-3'). The 16S rRNA gene sequence was then compared with the available sequences in the EzBioCloud database (https://www.ezbiocloud.net/ identify) using Identify Analysis (Yoon et al. 2017) and the NCBI database by 
using BLAST (Altschul et al. 1990). Phylogenetic trees of the $16 \mathrm{~S}$ rRNA gene were performed by using MEGA version 7.0 (Kumar et al. 2016) with the maximum-likelihood (Felsenstein 1981), neighbor-joining (Saitou et al. 1987), and maximum-parsimony (Fitch 1971) methods. Multilocus sequence analysis (MLSA) was used to infer the phylogenetic relation ships of strain TRM $85114^{\mathrm{T}}$ (de la Haba et al. 2012). The 16S rRNA, gyrB, and $r p o D$ gene sequence of strain TRM $85114^{\mathrm{T}}$ was aligned with those of the most closely related species by using CLUSTAL_X (Thompson et al. 1997). Bootstrap analysis was performed for 1000 replicates to estimate the confidence of branches in the phylogenetic trees generated (Felsenstein 1985). Evolutionary distances were calculated by using the Kimura two-parameter model (Kimura 1980).

\section{Genome sequencing and analysis}

Genomic DNA sequence was sequenced by the Illumina Hiseq platform and assembled by ABySS (version 2.0) assembler (Jackman et al. 2017). We used the software CheckM to evaluate the completeness and contamination of the genome (Parks et al. 2015), online prodigal to predict assembled genome (Hyatt et al. 2010), software tRNAscan-SE to predict the tRNA in the genome (Lowe et al. 1997), and the software Infernal 1.1 (Nawrocki et al. 2013) to predict the rRNA in the genome based on the Rfam (Nawrocki et al. 2015) database. Genome annotation obtained by Personal Biotechnology Co., Ltd (Shanghai, China). The DNA $\mathrm{G}+\mathrm{C}$ content was calculated based on the whole genome sequence. Calculations of the digital DNA-DNA hybridization $(\mathrm{dDDH})$ and the average 
nucleotide identity (ANI) values was performed by using the Genome-to-Genome Distance Calculator (GGDC, version 2.1; http://ggdc.dsmz.de/distcalc2.php) (Meier-Kolthoff et al. 2013) and the ChunLab's online ANI Calculator (www.ezbiocloud.net/tools/ani) (Lee et al. 2015), respectively. Moreover, a phylogenomic tree was drawn via the Type Strain Genome Server (TYGS; https://tygs.dsmz.de) (Meier-Kolthoff et al. 2019) to provide a whole genome-based taxonomic analysis .

\section{Detection of 1-naphthylamine degradation capacity}

Degradation of 1-naphthylamine on TRM $85114^{\mathrm{T}}$ growth was performed in batch experiments (Govarthanan et al. 2020). The isolate TRM 85114 ${ }^{\mathrm{T}}$ was inoculated into $250 \mathrm{~mL}$ Erlenmeyer flasks containing $100 \mathrm{~mL}$ of $12 \%$ MGM medium, and 50 $\mathrm{mg} / \mathrm{L}$ concentration of 1-naphthylamine was added into the culture flasks at the same time, the resuspension was incubated at $30{ }^{\circ} \mathrm{C}$ temperature in a shaking incubator (180 rpm) for 14 days. Sampling after incubation for 2day, 4day, 6day, 8day, 10day, 12day, and 14day, the extracted samples were detected to HPLC at $222 \mathrm{~nm}$ to analysis for the content of 1-naphthylamine. All the experiments were performed in triplicates and mean values were reported. Growth of the isolate without 1-naphthylamine was used as a control for this experiment. The 1-naphthylamine standard curve was drawn by the content of $20 \mathrm{mg} / \mathrm{L}, 40 \mathrm{mg} / \mathrm{L}$, $60 \mathrm{mg} / \mathrm{L}, 80 \mathrm{mg} / \mathrm{L}, 100 \mathrm{mg} / \mathrm{L}$ and $120 \mathrm{mg} / \mathrm{L}$. The elution procedure of the study was used methanol ranging from $10 \%$ to $100 \%$ to gradient elution for 40 minutes. 


\section{Results and discussion}

\section{Phenotypic, physiological characterization}

Strain TRM $85114^{\mathrm{T}}$ was aerobic, Gram-negative, Short rods, and non-motile bacteria (Fig. 1). After 4 days of incubation at $30{ }^{\circ} \mathrm{C}$, cream-white colonies grew on $12 \%$ MGM agar plates. The strain can tolerate $1-10 \%(\mathrm{w} / \mathrm{v}) \mathrm{NaCl}$ (optimum, 3\%), pH of 6.0-9.0 (optimum, 6.0), and grow at $4-35{ }^{\circ} \mathrm{C}$ (optimum, $30{ }^{\circ} \mathrm{C}$ ) .

Strain have the ability to hydrolyze starch, aesculin, Tween 20, 40 and 60, but not Tween 80, casein, DNA, gelatin, and urae. The strain was positive for methyl red test, catalase, oxidase, phenylalanine deaminase, reduction of nitrate to nitrite, respiration on nitrate and nitrite, and product $\mathrm{H}_{2} \mathrm{~S}$ from L-cysteine, but negative for indole production, Voges-Proskauer production, lysine and ornithine decarboxylases, and $o$-Nitrophenyl- $\beta$-D- galactopyranosidase activity. It also has the ability to ferment D-glucose to produce acid. This strain could produce poly- $\beta$-hydroxyalkanoate, but not for exopolysaccharides. $\mathrm{Mg}^{2+}, \mathrm{SO}^{2-}$ and $\mathrm{K}^{+}$ were not necessary elements for this strain to grow. In the API 20E system, strain can produce acid from D-glucose, rhamnose, and arabinose, not from mannitol, inositol, sorbitol, sucrose, melibiose, and amygdalin. In the API 20NE system, strain has ability to assimilation D-mannose and malic acid, not D-glucose, arabinose, mannose, mannitol, maltose, gluconate, hydroxydecanoate, citric acid, adipic acid, and phenylacetic acid. In the API 50CH system, D-glucose, D-fructose, mannitol, sorbitol, glycerin, inositol, glucuronic acid, maltose, and fumaric acid can be used as sole carbon sources to grow. The strain was be 
sensitive to the following antimicrobial agents (content per disc): vancomycin (30 $\mu \mathrm{g})$, penicillin $(1 \mu \mathrm{g})$, piperacillin $(100 \mu \mathrm{g})$, cefradine $(30 \mu \mathrm{g})$, ceftriaxone $(30 \mu \mathrm{g})$, cefoperazone $(75 \mu \mathrm{g})$, gentamicin $(10 \mu \mathrm{g})$, kanamycin $(30 \mu \mathrm{g})$, neomycin $(30 \mu \mathrm{g})$, erythromycin $(15 \mu \mathrm{g})$, norfloxacin $(10 \mu \mathrm{g})$, ofloxacin $(5 \mu \mathrm{g})$, ciprofloxacin $(5 \mu \mathrm{g})$, polymyxin $\mathrm{B}(300 \mu \mathrm{g})$ and bactrim $(25 \mu \mathrm{g})$. Resistant to ampicillin $(10 \mu \mathrm{g})$, carbenicillin $(100 \mu \mathrm{g})$, oxacillin $(1 \mu \mathrm{g})$, cefalexin $(30 \mu \mathrm{g})$, tetracycline $(30 \mu \mathrm{g})$, minocycline $(30 \mu \mathrm{g})$, clindamycin $(2 \mu \mathrm{g})$ and deoxytetra- cycline $(30 \mu \mathrm{g})$.

Numerous characteristics of the four reference strains were similar with strain TRM $85114^{\mathrm{T}}$. All of the five closely related strains were aerobic, positive for oxidase, catalase, poly- $\beta$-hydroxyalkanoate production, methyl red test, negative for $o$-Nitrophenyl- $\beta$-D-galactopyranosidase, lysine and ornithine decarboxylases and indole production. Furthermore, five strains have ability to hydrolyse aesculin and Tween20, not for Tween80, gelatin, casein, and DNA. Those five strains can not utilize mannitol, inositol, sucrose and amygdalin to produce acid (API 20E), nor assimilated arabinose, hydroxy- decanoate, and phenylacetic acid (API 20NE). The five reference strains were negative to use as carbon source from most substrates (API 50CH). Five strains were sensitive to the following antimicrobial agents (content per disc): penicillin $(1 \mu \mathrm{g})$, piperacillin $(100 \mu \mathrm{g})$, cefradine $(30$ $\mu \mathrm{g})$, ceftriaxone $(30 \mu \mathrm{g})$, cefoperazone $(75 \mu \mathrm{g})$, gentamicin $(10 \mu \mathrm{g})$, kanamycin (30 $\mu \mathrm{g})$, norfloxacin $(10 \mu \mathrm{g})$, ofloxacin $(5 \mu \mathrm{g})$, ciprofloxacin $(5 \mu \mathrm{g})$ and bactrim $(25 \mu \mathrm{g})$, not for minocycline $(30 \mu \mathrm{g})$. Otherwise, Several different characteristics among five strains and the type species of the genus, Halomonas elongata ATCC 
$3317^{\mathrm{T}}$, are shown in Table 1.

\section{Chemotaxonomic characteristics}

221 The predominate identified respiratory quinone of strain TRM $85114^{\mathrm{T}}$ was Q-9 $222(34.8 \%)$, others were Q-8 (15.2\%), Q-6 (4.7\%) and an unidentified component 223 (45.2\%), similar with the ubiquinone systems of members of the 224 genus Halomonas. As shown in Table 2, the primary cellular fatty acids of strain 225 TRM $85114^{\mathrm{T}}$ were identified as $\mathrm{C}_{16: 0}(18.0 \%)$ and $\mathrm{C}_{19: 0}$ cyclo $\omega 8 c(10.3 \%)$. 226 Several fatty acid profile of strain TRM $85114^{\mathrm{T}}$ was similar to the closely related species: the fatty acids $\mathrm{C}_{10: 0}(0.8 \%), \mathrm{C}_{11: 0} 3-\mathrm{OH}(0.3 \%)$ and $\mathrm{C}_{20: 2} \omega 6,9 c(0.3 \%)$ were predominant. Moreover, strain TRM $85114^{\mathrm{T}}$ differed from four reference strains by the types of fatty acids. In addition, the polar lipids of strain TRM $85114^{\mathrm{T}}$ were diphosphatidylglycerol, phosphatidylglycerol, phosphatidyl-

231 ethanolamine, lyso-phospatidylglycerol, phospholipids of unknown structure containing glucosarmine, and five unidentified lipids (Supplementary Fig. S1).

233 Two component of phosphatidylglycerol, phosphatidylglycerol and phosphatidyl234 ethanolamine were detected from most species of the genus Halomonas, but 235 lyso-phospatidylglycerol and phospholipids of unknown structure containing 236 glucosarmine were evidently different from the polar lipid profiles of other strains 237 (Lu et al. 2018; Zhang et al. 2016; Ramezani et al. 2020).

\section{Phylogenetic analysis of the 16S rRNA gene sequences}

Based on the EzBioCloud analysis, the 16S rRNA gene sequence of strain TRM 
241

of the genus Halomonas. It shared high 16S rRNA gene sequence similarity with the type strain of $H$. korlensis $\mathrm{XK} 1^{\mathrm{T}}$ ( $\mathrm{Li}$ et al. 2008) (97.3\%), followed by three other Halomonas species, including H. tibetensis pyc13 $3^{\mathrm{T}}$ (Lu et al. 2018) (96.4\%), H. urumqiensis BZ-SZ-XJ27 ${ }^{\mathrm{T}}$ (Zhang et al. 2016) (96.1\%), and H. daqiaonensis CGMCC $1.9150^{\mathrm{T}}$ (Qu et al. 2011) (96.0\%), and with other recognized Halomonas species and known species in another genus in the family Halomonadaceae were less than $96.0 \%$. Based on the 16S rRNA gene (1504bp), the maximum-likelihood phylogenetic tree and phylogenomic tree for whole genome-based taxonomic analysis (Fig. 2, 3), strain TRM $85114^{\mathrm{T}}$ clustered tightly with $H$. korlensis $\mathrm{XK} 1^{\mathrm{T}}$, forming an independent sub-cluster supported by high bootstrap values within the genus of Halomonas cluster. The neighbor-joining, maximum-parsimony and neighbor-joining algorithm based on the concatenated gene sequences (16S rRNA 1504bp; gyrB 472bp; rpoD 1243bp) phylogenetic trees (Supplementary Fig. S2, S3, S4) also shown the position of strain TRM $85114^{\mathrm{T}}$ with respect to other type strains in the genus Halomonas. All of the five kinds of phylogenetic trees shown TRM $85114^{\mathrm{T}}$ formed a distinct clade with others, indicated it was a novel species belonged to the genus Halomonas.

\section{Genomic features and analysis}

The obtained draft genome of TRM $85114^{\mathrm{T}}$ (accession no. JAHCLU000000000) was $4,126,476 \mathrm{bp}$ in length with a high sequence, which comprise of 60 contigs $(\mathrm{N} 50=190,960 \mathrm{bp})$ and 52 scaffolds $(\mathrm{N} 50=208,915 \mathrm{bp})$. The content of DNA $\mathrm{G}+\mathrm{C}$ was $61.6 \mathrm{~mol} \%$. The annotated genome encodes a total of 3902 genes, 
263

including 1666 protein-coding genes. A total of 3 rRNAs and 57 tRNAs were identified in the genome. Sequences of two complete $16 \mathrm{~S}$ rRNA genes found in the genome were identical to those obtained through the Sanger sequencing. Based on the KEGG orthology-based annotation, a total of 3544 genes (90.9\%) were annotated and assigned to putative functions, of which 1389 genes were annotated into metabolism-associated pathways, and 249 genes were annotated into environmental information processing pathways. There are 44 ORFs of enzymes involved in aromatic hydrocarbon degradation ability (Table S1), contig15_2804 (frmA, ADH5, adhC) was annotated for naphthalene degradation function. The $\mathrm{dDDH}$ and ANI value among strain TRM $85114^{\mathrm{T}}$ and four reference strains were conducted. The dDDH value between strain TRM $85114^{\mathrm{T}}$ with $H$. korlensis $\mathrm{XK} 1^{\mathrm{T}}, H$. tibetensis pyc13 ${ }^{\mathrm{T}}, H$. urumqiensis $\mathrm{BZ}-\mathrm{SZ}-\mathrm{XJ} 27^{\mathrm{T}}$, and $H$. daqiaonensis CGMCC $1.9150^{\mathrm{T}}$ were $39.2 \%, 25.0 \%, 25.7 \%$, and $28.1 \%$. The ANI value between them were $88.9 \%, 77.8 \%, 78.6 \%$, and $80.5 \%$. These data were all significantly lower than the threshold values for $\mathrm{dDDH}(70 \%)$ and ANI (95-96\%) used to discriminate bacterial species, respectively. The above data show that TRM $85114^{\mathrm{T}}$ was a novel strain of the genus Halomonas with naphthalene degradation ability.

\section{1-Naphthylamine degradation rate}

The biodegradation efficiency of the isolate TRM $85114^{\mathrm{T}}$ was further investigated. The result showed that the retention time of 1-naphthylamine was at 26 minute, and the absorption peak area of 1-naphthylamine decreased significantly with the 
increase of days (Fig. S5). According to the standard curve of 1-naphthylamine (Fig. S6), the degradation amount of 1-naphthylamine could reach up to 21.6 $\mathrm{mg} / \mathrm{L}$ at the 4 th day and $32.0 \mathrm{mg} / \mathrm{L}$ at the 14 th day (Fig. S7) by strain TRM $85114^{\mathrm{T}}$. Result indicated $\mathrm{TRM} 85114^{\mathrm{T}}$ has a strong ability to degrade 1-naphthylamine, it was a strain with environmental remediation ability by treating wastewater which contain 1-naphthylamine.

\section{Description of Halomonas jincaotanensis sp. nov.}

Halomonas jincaotanensis (jin.caotan.en' sis. NL fem. adj. jincaotanensis were pertaining to Jincaotan, Pamir Plateau, Xinjiang, China, from where the type strain was isolated).

Strain was Gram-stain-negative, aerobic, short-rod shape, and non-motile. The cell size was $0.9-1.0 \times 0.4-0.5 \mu \mathrm{m}$. Colonies were circular, cream-white, and convex with smooth surfaces when incubated on $12 \%$ MGM agar at $30{ }^{\circ} \mathrm{C}$ for 4 days. The strain can grows at $4-35{ }^{\circ} \mathrm{C}$ (optimum, $30^{\circ} \mathrm{C}$ ), $\mathrm{pH}$ of $6.0-9.0$ (optimum, $\mathrm{pH} 6.0$ ), and can tolerate $1-10 \%(\mathrm{w} / \mathrm{v}) \mathrm{NaCl}$ (optimum, $3 \%)$. Strain have ability to hydrolyze Starch, aesculin, Tween 20, 40 and 60 , but not Tween 80 , casein, DNA, gelatin, and urea. The strain was positive for catalase, oxidase, phenylalanine deaminase, reduction of nitrate to nitrite, ferment D-glucose to produce acid, respiration on nitrate and nitrite, product $\mathrm{H}_{2} \mathrm{~S}$ from L-cysteine, and methyl red test, but negative for indole production, Voges-Proskauer production, lysine and ornithine decarboxylases, and $o$-Nitrophenyl- $\beta$-D-galactopyranosidase 
activity. This strain could produce poly- $\beta$-hydroxyalkanoate, but not for exopolysaccharides. Grow without $\mathrm{Mg}^{2+}, \mathrm{SO}^{2-}$ and $\mathrm{K}^{+}$, produce acid from D-glucose, rhamnose, and arabinose, not from mannitol, inositol, sorbitol, sucrose, melibiose, and amygdalin. Besides, strain have ability to assimilation D-mannose and malic acid, not D-glucose, arabinose, mannose, mannitol, maltose, gluconate, hydroxydecanoate, citric acid, adipic acid, and phenylacetic acid. D-glucose, D-fructose, Mannitol, sorbitol, glycerin, inositol, glucuronic acid, maltose, and

314 fumaric acid can be used as sole carbon sources. Sensitive to the following antimicrobial: vancomycin, penicillin, piperacillin, cefradine, ceftriaxone, cefoperazone, gentamicin, kanamycin, neomycin, erythromycin, norfloxacin,

317 ofloxacin, ciprofloxacin, polymyxin B and bactrim. Resistant to ampicillin, 318 carbenicillin, oxacillin, cefalexin, tetracycline, minocycline, clindamycin and 319 deoxytetracycline. The predominate respiratory quinone was Q-9. The major fatty 320 acids of the cells were $\mathrm{C}_{16: 0}$ and $\mathrm{C}_{19: 0}$ cyclo $\omega 8 c$. The polar lipids were 321 diphosphatidylglycerol, phosphatidylglycerol, phosphatidylethanolamine, lyso322 phospatidylglycerol, phospholipids of unknown structure containing 323 glucosarmine, and five unidentified lipids. The DNA G+C content of the strain was $61.6 \mathrm{~mol} \%$. The degradation of 1-naphthylamine could reach up to 32.0 $325 \mathrm{mg} / \mathrm{L}$ in 14 days.

The type strain, TRM $85114^{\mathrm{T}}\left(=\mathrm{CCTCC}\right.$ AB $\left.2021006^{\mathrm{T}}=\mathrm{LMG} 32311^{\mathrm{T}}\right)$, was isolated from the wetland soil of Jincaotan in Pamir Plateau. The GenBank accession numbers for the $16 \mathrm{~S}$ rRNA gene and the draft genome sequence of 
TRM $85114^{\mathrm{T}}$ are MW584241 and JAHCLU000000000, respectively.

\section{Acknowledgment}

332 Our research was supported by the National Natural Science Foundation of China 333 (31900007), Bingtuan Science and Technology Program (2018BC008), and 334 Microbial Resources Utilization Innovation Team in Key Field of Xin Jiang 335 Production and Construction Corps (2017CB014), and the principal fund 336 (TDHNLH201604).

\section{Author contributions}

$338 \mathrm{XB}$ performed the experiment, analyzed the data, and drafted the manuscript. ZL 339 contributed to guiding the degradation test of 1-naphthylamine. ZX, CW, MR 340 critically revised the manuscript. LZ contributed to the creation of the project. All 341 authors read and approved the manuscript. We thank HC and PX for finding and 342 providing Halomonas tibetensis pyc13 ${ }^{\mathrm{T}}$.

343 Disclosure statement

\section{Conflict of interest}

345 All authors declare no conflict of interest.

346 Ethical approval

347 No specific ethical or institutional permission is required for sampling, and 348 experimental studies do not involve endangered or protected species. 
Table 1 Differential characteristics of strain TRM $85114^{\mathrm{T}}$ and the type strains of related species of the genus Halomonas.

Table 2 Compositions of the cellular fatty acids of strain TRM $85114^{\mathrm{T}}$ and its four reference strains.

Fig. 1 Scanning electron microscope image of TRM $85114^{\mathrm{T}}$ cells grown on $12 \%$ MGM at $30{ }^{\circ} \mathrm{C}$ for 3 days. Scale bar, $2 \mu \mathrm{m}$.

Fig. 2 Maximum-likelihood tree based on 16S rRNA gene sequences showing the phylogenetic relationships between strain TRM $85114^{\mathrm{T}}$ and related taxa. Bootstrap values over $50 \%$ are shown on the nodes as percentages of 1,000 replicates. Pseudomonas frederiksbergensis DSM $13022^{\mathrm{T}}$ (NR028906) was used as an outgroup. Bars indicate 0.01 changes per nucleotide position.

Fig. 3 Phylogenomic tree of strains TRM $85114^{\mathrm{T}}$ and related type strains available on the TYGS database. The numbers above branches are GBDP pseudo-bootstrap support values from 100 replications.

Table S1 KEGG annotation analysis of enzymes involved in aromatic hydrocarbon degradation ability based on TRM $85114^{\mathrm{T}}$ genome.

Fig. S1 Two-dimensional thin-layer chromatograms showing the polar lipids of strain TRM $85114^{\mathrm{T}}$ with a different chromogenic agent. a, 10\% ethanolic molybdophosphoric acid reagent; b, ninhydrin reagent; c, molybdenum blue reagent; d, anisaldehyde reagent. DPG, diphosphatidylglycerol; PG, phosphatidylglycerol; PE, phosphatidylethanolamine; LPG, lyso-phospatidylglycerol; NPG, phospholipids of unknown structure containing glucosarmine; PL, unidentified 
lipids.

Fig. S2 Neighbour-joining tree based on 16S rRNA gene sequences showing the phylogenetic relationships between strain TRM $85114^{\mathrm{T}}$ and related taxa. Bootstrap values over $50 \%$ are shown on the nodes as percentages of 1,000 replicates. Pseudomonas frederiksbergensis DSM 13022 ${ }^{\mathrm{T}}$ (NR028906) was used as an outgroup. Bars indicate 0.01 changes per nucleotide position.

Fig. S3 Maximum-parsimony tree based on 16S rRNA gene sequences showing the phylogenetic relationships between strain TRM $85114^{\mathrm{T}}$ and related taxa. Bootstrap values over $50 \%$ are shown on the nodes as percentages of 1,000 replicates. Pseudomonas frederiksbergensis DSM $13022^{\mathrm{T}}$ (NR028906) was used as an outgroup.

Fig. S4 Phylogenetic tree generated with the neighbor-joining algorithm based on the concatenated gene sequences (16S rRNA 1504bp; gyrB 472bp; rpoD 1243 bp) gene sequences showing the phylogenetic positions of strain TRM $85114^{\mathrm{T}}$ and related taxa. Bootstrap values with more than $50 \%$ are shown on the nodes as percentages of 1,000 replicates. Pseudomonas frederiksbergensis DSM $13022^{\mathrm{T}}$ was used as an outgroup. The scale bar equals 0.01 changes per nucleotide position.

Fig. S5 HPLC analysis of TRM $85114^{\mathrm{T}}$ grew with 1-naphthylamine in 12\% MGM medium under absorption wavelength of $222 \mathrm{~nm}$. The absorb peak of 1-naphthylamine at 26 min. a, TRM $85114^{\mathrm{T}}$ cultured with 1 -naphthylamine at 0 day; b, at 2nd day; c, at 4th day; d, 6th day; e, 8th day; f, 10th day; g, 12th day; h, 14th day.

Fig. S6 Standard curve of 1-naphthylamine. 1-Naphthylamine absorb peak area as 
the abscissa and content as the longitudinal coordinate. Data obtained by HPLC under absorption wavelength of $222 \mathrm{~nm}$.

Fig. S7 Time course of 1-naphthylamine biodegradation by TRM $85114^{\mathrm{T}}$ during growth in $12 \%$ MGM medium.

\section{References}

Altschul SF, Gish W, Miller W, Myers EW, Lipman DJ (1990) Basic local alignment search tool. J Mol Biol 215:403-410

Arahal DR, Vreeland RH, Litchfield CD, Mormile MR, Tindall BJ, Oren A, Bejar V, Quesada E, Ventosa A (2007) Recommended minimal standards for describing new taxa of the family Halomonadaceae. Int J Syst Evol Microbiol 57:2436-2446

Collins MD, Pirouz T, Goodfellow M, Minnikin DE (1977) Distribution of menaquinones in actinomycetes and corynebacteria. J Gen Microbiol 100:221-230

Collins MD (1985) Isoprenoid quinone analysis in classification and identification. Soc Appl Bacteriol Tech 20:267-287

de la Haba RR, Ma'rquez MC, Papke RT, Ventosa A (2012) Multilocus sequence analysis of the family Halomonadaceae. Int J Syst Evol Microbiol 62:520-538

Dong XZ, Cai MY (2001) Determinative manual for routine bacteriology. Beijing Scientific Press, Beijing, China.

Dou G, He W, Yuchao, Liu H, Ma Y (2015) Halomonas heilongjiangensis sp. nov. a novel moderately halophilic bacterium isolated from saline and alkaline soil. Antonie Van Leeuwenhoek 10:482-493

Du H, Zhao Y, Wu F, Ouyang P, Chen J, Jiang X, Ye J, Chen GQ (2020) Engineering Halomonas bluephagenesis for L-Threonine production. Metab Eng 60:119-127

Farraj D, Hadibarata T, Yuniarto A, Alkufeidy R, Alshammari M, Syafuddin A (2020) Exploring the potential of halotolerant bacteria for biodegradation of polycyclic aromatic hydrocarbon. Bioproc and Biosyst Eng 43:2305-2314

Felsenstein J (1981) Evolutionary trees from DNA sequences: a maximum likelihood approach. J Mol Evol 17:368-376

Felsenstein J (1985) Confidence limits on phylogenies: an approach using the bootstrap. Evolution 39:783-791

Fitch WM (1971) Toward defining the course of evolution: minimum change for a specific tree topology. Syst Zool 20:406-416

Govarthanan M, Khalifa A, Kamalakannan S, Srinivasan P, Selvankumar T, Selvam K, Kim W (2020) Significance of allochthonous brackish water Halomonas sp. on biodegradation of low and high molecular weight polycyclic aromatic hydrocarbons. Chemosphere 243:125389

Hu J, Shao D, Chen C, Sheng G, Ren X, Wang X (2011) Removal of 1-naphthylamine from 
aqueous solution by multiwall carbon nanotubes/iron oxides/cyclodextrin composite. J Hazard Mater 185:463-471

Hyatt D, Chen GL, Locascio PF, Land ML, Larimer FW, Hauser LJ (2010) Prodigal: prokaryotic gene recognition and translation initiation site identifcation. BMC Bioinform 11:119-130

Jackman SD, Vandervalk BP, Mohamadi H, Chu J, Yeo S, Hammond SA, Jahesh G, Khan H, Coombe L, Warren RL, Birol I (2017) ABySS 2.0: resource-efficient assembly of large genomes using a Bloom filter. Genome Res 27:768-777

Jiang XR, Jin Y, Chen XB, Chen GQ (2018) Halomonas and Pathway Engineering for Bioplastics Production. Methods Enzymol 608:309-328

Jiang XR, Yan X, Yu LP, Liu XY, Chen GQ (2021) Hyperproduction of 3-hydroxypropionate by Halomonas bluephagenesis. Nat Commun 12:1513-1526

Kazemi E, Tarhriz V, Amoozegar MA, Mohammad SH (2020) Halomonas azerbaijanica sp. nov. a halophilic bacterium isolated from Urmia Lake after the 2015 drought. Int J Syst Evol Microbiol 71:4578-4586

Kimura M (1980) A simple method for estimating evolutionary rates of base substitutions through comparative studies of nucleotide sequences. J Mol Evol 16:111-120

Koh HW, Rani S, Kim SJ, Moon E, Nam SW, Rhee SK, Park SJ (2017) Halomonas aestuarii sp. nov. a moderately halophilic bacterium isolated from a tidal flat. Int J Syst Evol Microbiol 67:4298-4303

Lee I, Kim YO, Park SC, Chun J (2015) Orthoani: an improved algorithm and software for calculating average nucleotide identity. Int J Syst Evol Microbiol 66:1100-1103

Li HB, Zhang LP, Chen SF (2008) Halomonas korlensis sp. nov., a moderately halophilic, denitrifying bacterium isolated from saline and alkaline soil. Int J Syst Evol Microbiol 58: 2582-2588

Lowe TM, Eddy SR (1997) tRNAscan-SE: a program for improved detection of transfer RNA genes in genomic sequence. Nucleic Acids Res 25:955-964

Lu HB, Xing P, Zhai L, Phurbu D, Tang Q, Wu QL (2018) Halomonas tibetensis sp. nov. isolated from saline lakes on Tibetan Plateau. J Microbiol 56:493-499

Mata JA, Martínez-Cánovas J, Quesada E, Béjar V (2002) A detailed phenotypic characterisation of the type strains of Halomonas species. Syst Appl Microbiol 25: 360-375

Meier-Kolthoff JP, Auch AF, Klenk HP, Go“ker M (2013) Genome sequence-based species delimitation with confidence intervals and improved distance functions. BMC Bioinform $14: 60$

Meier-Kolthoff JP, Göker M (2019) TYGS is an automated highthroughput platform for state-of-the-art genome-based taxonomy. Nat Commun 10:1-10

Minnikin DE, O’Donnell AG, Goodfellow M, Alderson G, Athalye M, Schaal K, Parlett JH (1984) An integrated procedure for the extraction of bacterial isoprenoid quinones and polar lipids. J Microbiol Methods 2:233-241

Nawrocki EP, Eddy SR (2013) Infernal 1.1:100-fold faster RNA homology searches. Bioinformatics 29:2933-2935

Nawrocki EP, Burge SW, Bateman A, Daub J, Eberhardt RY, Eddy SR, Floden EW, Gardner PP, Jones TA, Tate J, Finn RD (2015) Rfam 12.0: updates to the RNA families database. Nucleic Acids Res 43:130-137 
Nguyen HTT, Nielsen JL, Nielsen PH (2012) 'Candidatus Halomonas phosphatis', a novel polyphosphate-accumulating organism in full-scale enhanced biological phosphorus removal plants. Environ Microbiol 14: 2826-2837

Parks DH, Imelfort M, Skennerton CT, Hugenholtz P, Tyson GW (2015) CheckM: assessing the quality of microbial genomes recovered from isolates, single cells, and metagenomes. Genome Res 25:1043-1055

Poli A, Nicolaus B, Denizci AA, Yavuzturk B, Kazan D (2013) Halomonas smyrnensis sp. nov. a moderately halophilic, exopolysaccharide-producing bacterium. Int J Syst Evol Microbiol 63:10-18

Qu LY, Lai QL, Zhu FL, Hong XG, Zhang ZX, Shao ZZ, Sun XQ (2011) Halomonas daqiaonensis sp. nov., a moderately halophilic, denitrifying bacterium isolated from a littoral saltern. Int J Syst Evol Microbiol 61:1612-1616

Ramezani M, Pourmohyadini M, Nikou MM, Makzum S, Schumann P, Clermont D, Criscuolo A, Amoozegar MA, Kämpfer P, Spröer C (2020) Halomonas lysinitropha sp. nov. a novel halophilic bacterium isolated from a hypersaline wetland. Int J Syst Evol Microbiol 70:6098-6105

Saitou N, Nei M (1987) The neighbor-joining method: a new method for reconstructing phylogenetic tree. Mol Biol Evol 4: 406-425

Sasser M (1990) Identification of bacteria by gas chromatography of cellular fatty acids. Midi Technical Note 101

Smith MD (2009) The Halohandbook. Protocols for haloarchaeal genetics, version 7.2. http://www.haloarchaea.com/resources/halohandbook

Kumar S, Stecher G, Tamura K (2016) MEGA7: molecular evolution ary genetics analysis version 7.0 for bigger datasets. Mol Biol Evol 33:1870-1874

Thompson JD, Gibson TJ, Plewniak F, Jeanmougin F, Higgins DG (1997) The CLUSTAL_X windows interface: flexible strategies for multiple sequence alignment aided by quality analysis tools. Nucleic Acids Res 25:4876-4882

Tuma S, Izaguirre JK, Bondar M, Marques MM, Fernandes P, da Fonseca MMR, Cesário MT (2020) Upgrading end-of-line residues of the red seaweed Gelidium sesquipedale to polyhydroxyalkanoates using Halomonas boliviensis. Biotechnol Rep 27:e00491

Vreeland RH, Litchfield CD, Martin EL, Elliot E (1980) Halomonas elongata, a new genus and species of extremely salttolerant bacteria. Int J Syst Evol Microbiol 30:485-495

Xu L, Xu XW, Meng FX, Meng FX, Huo YY, Oren A, Yang JY, Wang CS (2013) Halomonas zincidurans sp. nov. a heavy-metal-tolerant bacterium isolated from the deep-sea environment. Int J Syst Evol Microbiol 63:4230-4236

Yang Y, Pei Z, Yan L, Ma J, Zhang Z, Li Y, Yang R, Wang P, Zhu Y, Zhang Q (2020) Oxidative transformation of 1-naphthylamine in water mediated by different environmental black carbons. J Hazard Mater 403:123594

Yoon SH , Ha SM, Kwon S, Lim J, Kim Y, Seo H, Chun J (2017) Introducing EzBioCloud: a taxonomically United database of $16 \mathrm{~S}$ rRNA gene sequences and whole-genome assemblies. Int J Syst Evol Microbiol 67:1613-1617

Zhang SS, Pan J, Lu WD, Yan YC, Wang HS, Wiegel J, Zhao BS (2016) Halomonas urumqiensis sp. nov., a moderately halophilic bacterium isolated from a saline-alkaline lake. Int J Syst Evol Microbiol 66:1962-1969 
Zhong ZP, Liu Y, Wang F, Zhou YG, Liu HC, Liu ZP (2016) Lacimicrobium alkaliphilum gen. nov., sp. nov., a member of the family Alteromonadaceae isolated from a salt lake. Int $\mathrm{J}$ Syst Evol Microbiol 66:422-429

Zhou L, Chen X, Du Z, Mu D (2019) Halomonas chinensis sp. nov., a cellulose-decomposing bacterium from Arctic tundra soil. Int J Syst Evol Microbiol 69:1926-1933 


\section{Figures}

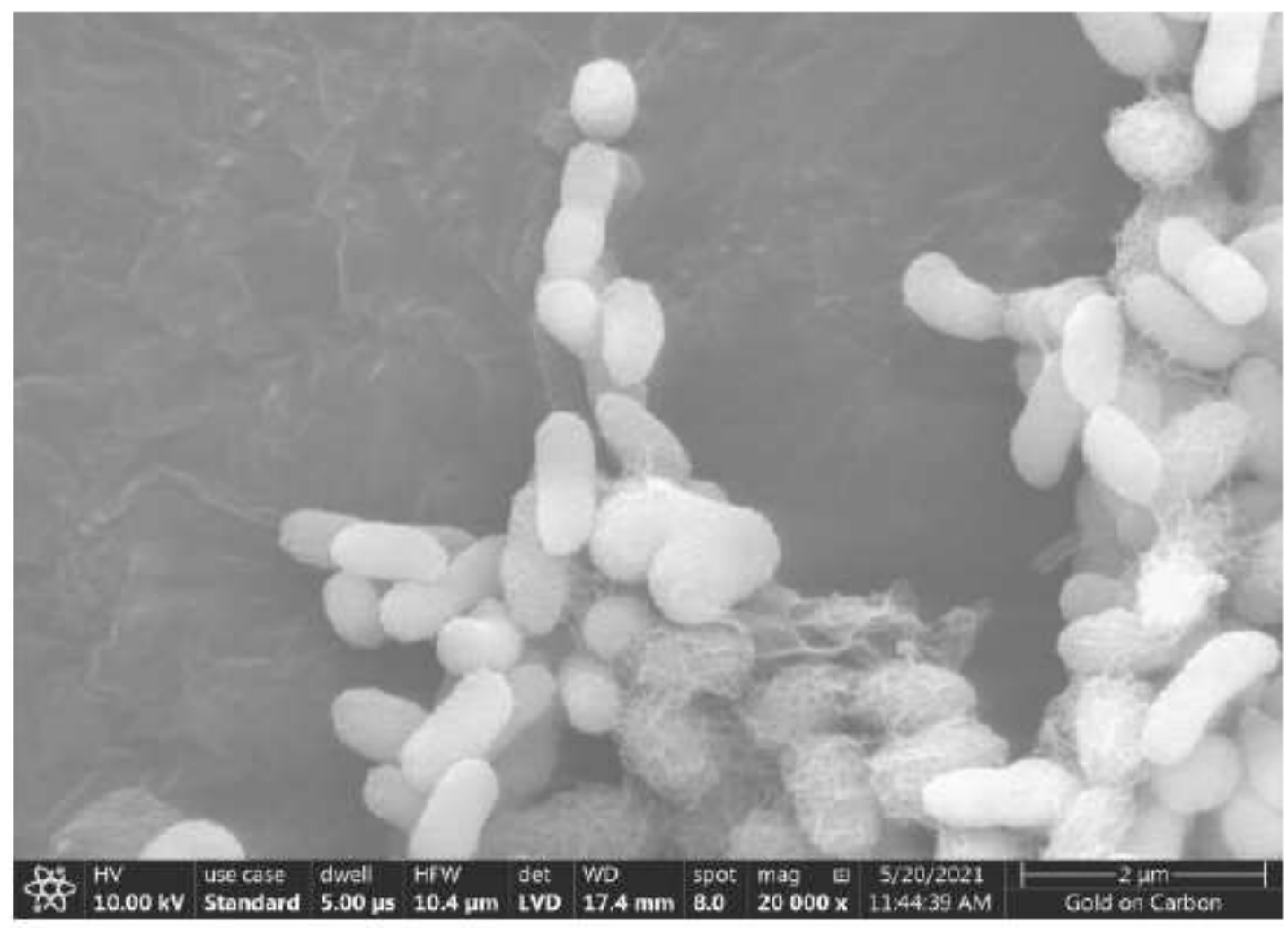

\section{Figure 1}

Scanning electron microscope image of TRM 85114 T cells grown on $12 \%$ MGM at $30 \otimes$ for 3 days. Scale bar, $2 \mu \mathrm{m}$. 


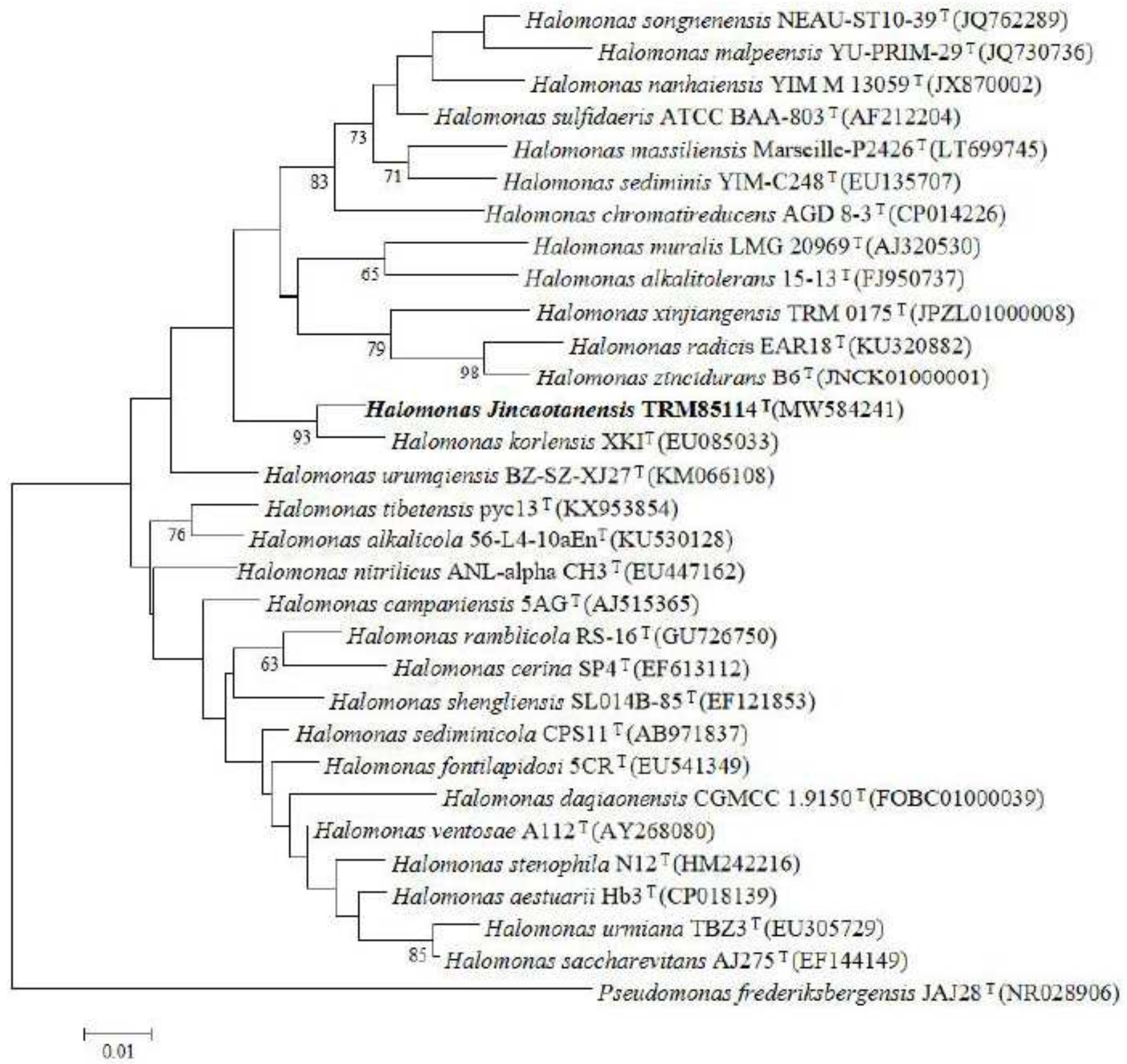

\section{Figure 2}

Maximum-likelihood tree based on 16S rRNA gene sequences showing the phylogenetic relationships between strain TRM 85114T and related taxa. Bootstrap values over $50 \%$ are shown on the nodes as percentages of 1,000 replicates. Pseudomonas frederiksbergensis DSM 13022T (NR028906) was used as an outgroup. Bars indicate 0.01 changes per nucleotide position. 


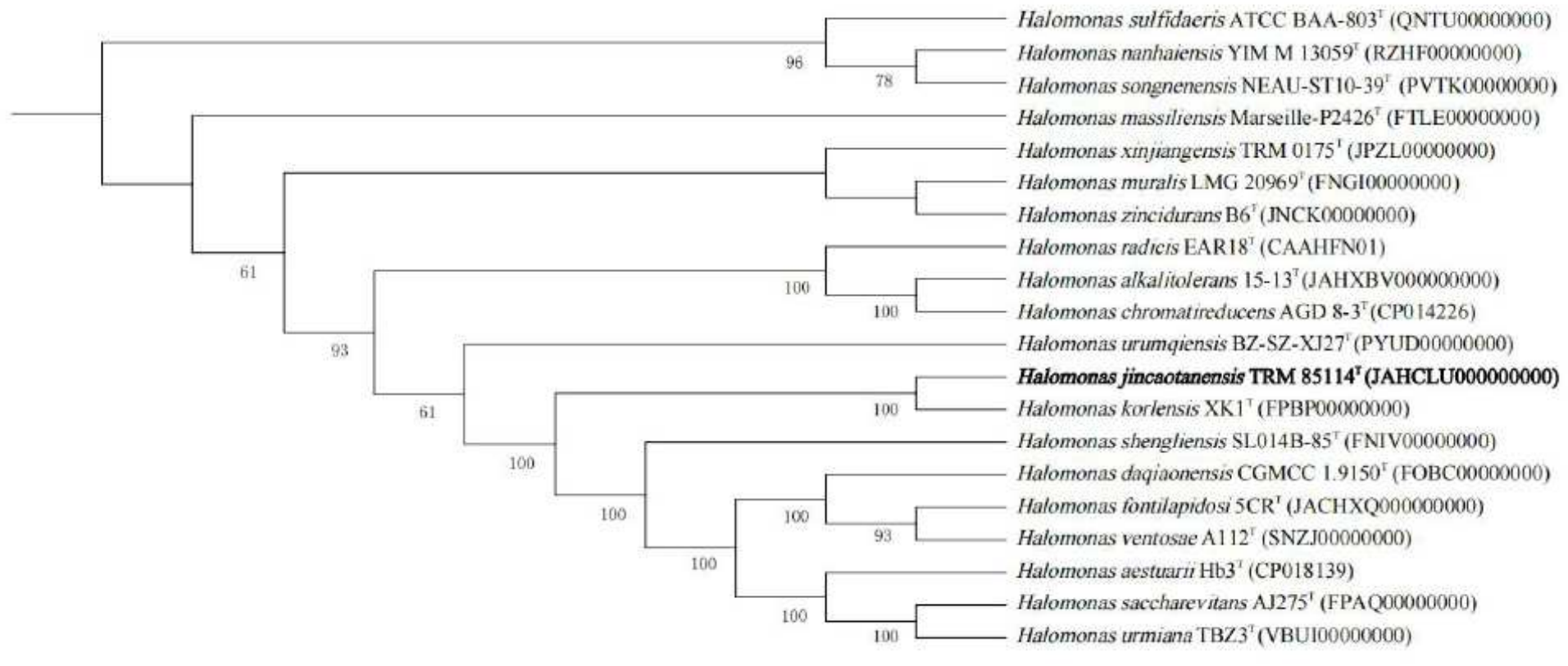

Figure 3

Phylogenomic tree of strains TRM 85114T and related type strains available on the TYGS database. The numbers above branches are GBDP pseudo-bootstrap support values from 100 replications.

\section{Supplementary Files}

This is a list of supplementary files associated with this preprint. Click to download.

- Tables.pdf

- SupplementaryData.pdf 